\title{
Behaviour of sea urchin Strongylocentrotus droebachiensis grazing fronts: food-mediated aggregation and density-dependent facilitation
}

\author{
Jean-Sébastien Lauzon-Guay ${ }^{1,3, *}$, Robert E. Scheibling ${ }^{2}$ \\ ${ }^{1}$ Biology Department, University of New Brunswick, Bag Service 45111, Fredericton, New Brunswick E3B 6E1, Canada \\ ${ }^{2}$ Department of Biology, Dalhousie University, Halifax, Nova Scotia B3H 4J1, Canada \\ ${ }^{3}$ Present address: Department of Biology, Dalhousie University, Halifax, Nova Scotia B3H 4J1, Canada
}

\begin{abstract}
The occurrence of destructive grazing fronts is a common phenomenon in sea urchins, but mechanisms governing front formation and dynamics remain poorly understood. We experimentally examined the effect of kelp biomass on the aggregative behavior and movement of a front of green sea urchins Strongylocentrotus droebachiensis at a wave-exposed site on the Atlantic coast of Nova Scotia. We varied kelp (Laminaria digitata and L. longicruris) abundance in $2 \times 2 \mathrm{~m}$ plots adjacent to the front in 3 treatments: $50 \%$ plant removal, and 100\% frond removal and unmanipulated control. In each treatment, we monitored the position of the front and urchin density at the leading edge over $24 \mathrm{~d}$. The mean advance of the front in $24 \mathrm{~d}(2.27 \mathrm{~m})$ did not differ between treatments, but urchin density was greatest in the control $\left(74.9\right.$ urchins $0.25 \mathrm{~m}^{-2}$ ) and lower in whole plant (54.3) and frond (39.4) removal treatments. When urchin density was used as a covariate, front advance was inversely related to kelp biomass and greater in frond and plant removal treatments than in the control. Together, urchin density and kelp biomass explained $75 \%$ of variation in front advance. These findings provide the first direct evidence that urchins redistribute themselves along a front to concentrate in patches of greatest food availability. Temporal variation in urchin density at the front was inversely correlated with wave height, and individual grazing rates increased with urchin density, which may explain seasonal variation in front dynamics observed in previous studies.
\end{abstract}

KEY WORDS: Sea urchin · Strongylocentrotus droebachiensis $\cdot$ Kelp bed · Feeding front · Barrens · Aggregation · Grazing $\cdot$ Density-dependent facilitation

\section{INTRODUCTION}

Feeding aggregations are common in many types of animals and have been related to various causal factors (Parrish \& Edelstein-Keshet 1999). For example, animals may aggregate to facilitate prey capture (Stander 1992) or to confer protection against predators (Jensen \& Larsson 2002). Alternatively, aggregations may arise passively in response to patches of high food quality (Clua \& Grosvalet 2001). In some cases, feeding aggregations exhibit a distinctive pattern and consume a food patch in an organized manner. One such pattern, which has been observed in wide range of animals, is the formation of a feeding front (e.g. locusts, Collett et al. 1998; queen conch, Stoner \& Lally 1994; and sea urchins, Breen \& Mann 1976). Individuals in feeding fronts are organized into a relatively narrow band that can span 100s of meters along the edge of a food patch and consume the resource progressively. These fronts are generally cohesive and maintain a relatively linear shape over time, even when patch quality varies spatially.

The formation of grazing fronts is commonly observed in sea urchins (e.g. Lytechinus variegatus, Rose et al. 1999; Heliocidaris erythrogramma, Wright et al. 2005; Strongylocentrotus droebachiensis, Scheibling \& 
Hatcher 2001). These fronts can be comprised of up to 1072 individuals $\mathrm{m}^{-2}$ (Foreman 1977) aggregating at the lower margin of kelp or seagrass beds. Urchin fronts are dynamic aggregations that can destructively graze macrophyte communities (Mann 1982), resulting in reduced biodiversity, primary productivity and habitat complexity (Rose et al. 1999). Although feeding fronts are a common feature among populations of sea urchins, our understanding of mechanisms leading to front formation, and governing the dynamics of destructive grazing, is limited.

The green sea urchin Strongylocentrotus droebachiensis provides an excellent model to test hypotheses about front dynamics. Grazing fronts have been reported throughout the circumpolar range of this species (NE Atlantic, Hagen 1987, Hjörleifsson et al. 1995, Sivertsen 1997; NW Atlantic, Breen \& Mann 1976, Scheibling et al 1999, Gagnon et al. 2004; and NE Pacific, Foreman 1977) and there is a wealth of information on its ecology and behavior (Scheibling \& Hatcher 2001). The process of front formation in S. droebachiensis initiates a phase shift from the kelp bed state to the urchin barrens state in shallow temperate waters (Chapman \& Johnson 1990); in the absence of grazing fronts, kelp beds persist for protracted periods (Chapman \& Johnson 1990). Once a front has formed, it can advance at rates of up to $4 \mathrm{~m} \mathrm{mo}^{-1}$ through a kelp bed (Scheibling et al. 1999, Gagnon et al. 2004), denuding the area of all fleshy seaweeds and leaving barrens dominated by encrusting coralline algae in its wake. The rate of advance of urchin fronts has been correlated with urchin density in some cases (Breen \& Mann 1976, Scheibling et al. 1999), but not others (Gagnon et al. 2004).

In recent years, the dynamics of the urchin-kelp system in the NW Atlantic has been altered by a series of invasions (Harris \& Tyrrell 2001). An invasive bryozoan, Membranipora membranacea, which settles and grows on kelp fronds, renders kelps more susceptible to breakage in strong surge conditions (Dixon et al. 1981). Heavy infestation by $M$. membranacea can cause total defoliation of kelp canopies, leaving only stipes that degenerate over time (Scheibling et al. 1999). This results in a massive loss of standing kelp biomass and a change in the physical structure of the kelp bed. To predict the potential impact of such defoliation events on the persistence of kelp beds, it is essential to understand how loss of the canopy affects the behavior of urchin feeding fronts (Scheibling et al. 1999).

This study experimentally examines the interactive effects of urchin density and kelp biomass on the aggregative behavior of urchins and rate of advance of an urchin front. Because fronts are essentially feeding aggregations, the rate of movement through a kelp bed should be a function of the rate at which the food resource (kelp and understory seaweeds) is being consumed. In turn, consumption rate should be correlated with the amount of resource available, the number of consumers, and individual feeding rate. Thus, we predicted that the rate of advance of a front would be directly related to urchin density and inversely related to kelp biomass. We also examined spatial and temporal variation in the degree of aggregation along an urchin front, and how this was related to biotic and abiotic features such as wave action. Our results expand our general understanding of pattern formation in grazing aggregations, and provide insights into the foraging behavior of the green sea urchin.

\section{MATERIALS AND METHODS}

Study site. This study was conducted at Splitnose Point $\left(44^{\circ} 28.609^{\prime} \mathrm{N}, 63^{\circ} 32.741^{\prime} \mathrm{W}\right)$ at the mouth of Ketch Harbour on the Atlantic coast near Halifax, Nova Scotia, Canada (Fig. 1). The site along the western shore of this long inlet is exposed to oceanic swells from the south and southeast. The substratum is char-

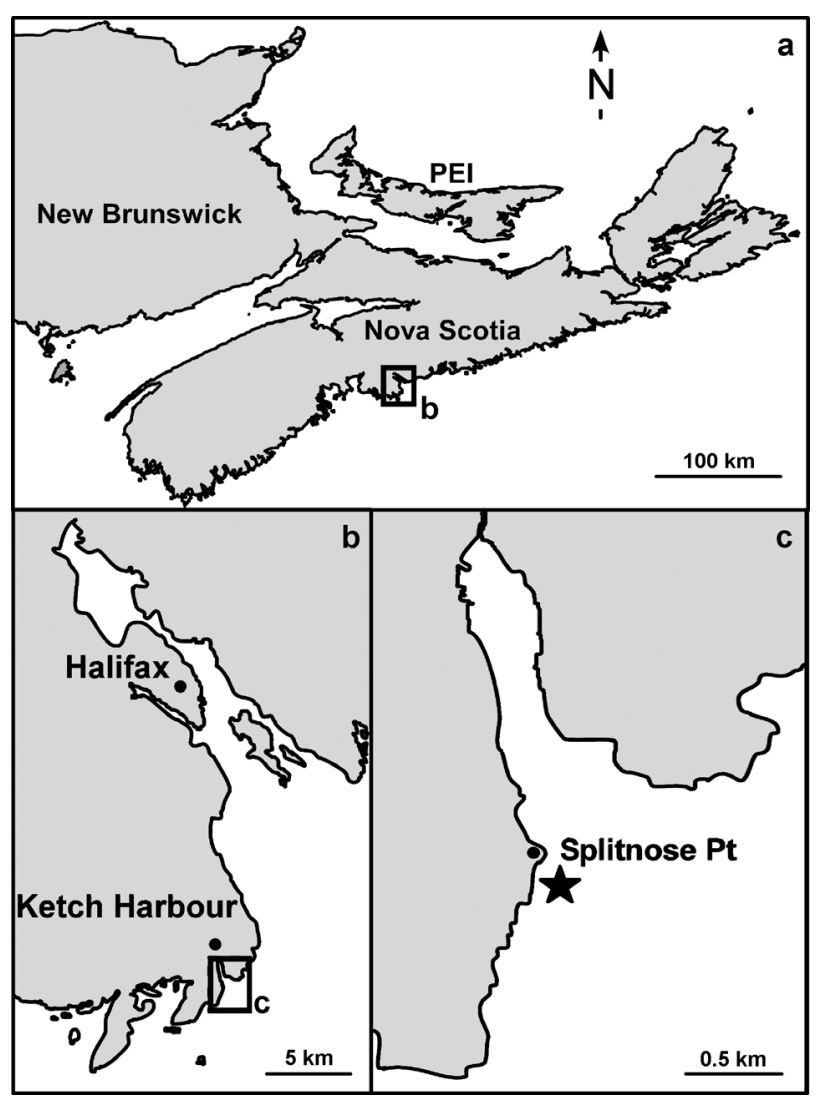

Fig. 1. (a) Atlantic Canada; (b) Halifax and Ketch Harbour area; (c) Splitnose Point. Star indicates location of study site 
acterized by gently sloping granite bedrock with irregular ledges and crevices. At the start of this study in July 2005, a kelp bed composed mainly of Laminaria longicruris and L. digitata extended from shallow water to a depth of 10 to $12 \mathrm{~m}$ (below chart datum) over an offshore distance of $\sim 150 \mathrm{~m}$. Another kelp, Alaria esculenta, occurred sporadically among the Laminaria spp. along the offshore extent of the bed, but was the dominant canopy-forming species in shallower water $(<5 \mathrm{~m})$. The understorey seaweeds were mainly foliose (Chondrus crispus, Phycodrys rubens) and filamentous (Ptilota serrata) turf-forming species. A dense front of large Strongylocentrotus droebachiensis was destructively grazing all kelps and associated seaweeds along the lower margin of the kelp bed, leaving only encrusting coralline algae (Lithothamnion glaciale, Phymatolithon lenormandii) and sponges (Halichondria panicea, H. bowerbanki and Isodyctya palmata) in its wake. Urchins behind the front were generally smaller and much less dense but extended throughout the barrens to a depth of $\sim 35 \mathrm{~m}$, where the substratum shifted to a sandy bottom. Mean daily water temperature at $12 \mathrm{~m}$ depth averaged $7.7^{\circ} \mathrm{C}( \pm 1.7 \mathrm{SD})$ during the course of our experiment (StowAway TidbiT Temp Logger, Onset Computer Corporation, Cape Cod, MA).

Experimental design. The experimental area extended $100 \mathrm{~m}$ (linear dis-

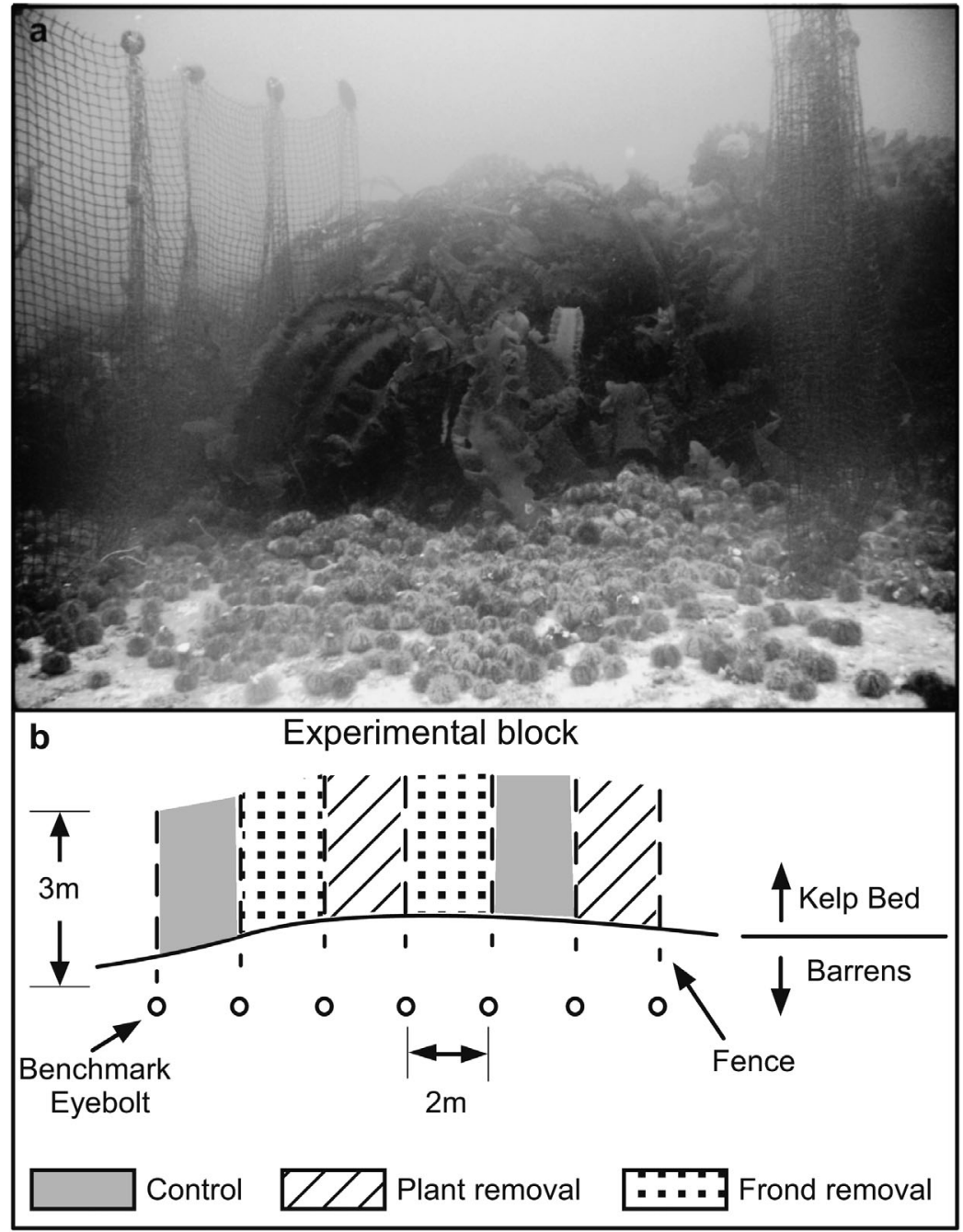

Fig. 2 (a) Photograph showing an experimental plot with surrounding fences and interface between the kelp bed and urchin barrens, with a dense front of Strongylocentrotus droebachiensis; (b) schematic representation of experimental block

tance) along the interface between the kelp bed and urchin barrens, and was divided into 4 roughly equal blocks, each block spanning between 12 and $20 \mathrm{~m}$. Each block was divided into 6 plots that were $2 \times 2 \mathrm{~m}$ and delineated by fences (1.5 $\mathrm{m}$ high $\times 3 \mathrm{~m}$ long) aligned perpendicular to the front and extending from $0.5 \mathrm{~m}$ into the barrens to $2.5 \mathrm{~m}$ into the kelp bed (Fig. 2). The fences allowed urchins at the front to move along the kelp/barrens interface between plots, but prevented faster moving sections of the front in some plots from grazing kelp along the sides of adjacent plots where the urchins advanced more slowly. Thus, fences maintained a consistent direction of front advance among all plots. The fences were constructed of aquaculture netting (mesh aperture $4 \mathrm{~cm}^{2}$ ) treated with an anti-foulant coating. Each fence was anchored with a heavy metal chain (link diameter $12 \mathrm{~mm}$ ) sewn along the bottom, and suspended by small plastic floats sewn along the top. The chain conformed to topographic irregularities creating an effective barrier to urchin movement between plots. The mesh size was impermeable to the large urchins that composed the front but offered relatively low resistance to water flow, although the fences swayed to and fro in heavy wave surge. Urchins were rarely observed climbing fences. As the front advanced, the fences were moved back into the kelp bed by divers as required to retain the same position relative to the kelp-barrens interface.

To examine the effect of kelp density/biomass on the rate of advance of the sea urchin front, we applied 3 treatments to $2 \times 2 \mathrm{~m}$ plots within the kelp bed:

(1) Unmanipulated control: to provide a baseline rate of advance for the sea urchin front within fenced plots 
in the kelp bed. (2) Plant removal treatment: to determine whether kelp density/biomass has an effect on the rate of advance of the front. We removed $50 \%$ of the kelp in a plot by removing every second plant encountered in a sweep from the interface into the kelp bed. Plants were cut at the base of the stipe, leaving the holdfast attached to the bottom. We predicted an increase in the rate of advance of the front in plots with $50 \%$ of kelp removed compared to the control treatment. (3) Frond removal treatment: to mimic the defoliation of a kelp bed following a severe infestation by Membranipora membranacea and to determine how this would affect the rate of advance of an urchin front. We removed the frond(s) of every kelp plant in a plot by cutting the frond away at the base, leaving the entire stipe and the holdfast intact.

We predicted that if the rate of destructive grazing was based solely on the available kelp biomass, the front should advance more rapidly in plots where fronds were removed than in control plots. Because stipes accounted for $\sim 30 \%$ of kelp biomass (fronds plus stipe, see 'Results'), we also predicted that the rate of front advance in the frond removal treatment should be similar or slightly higher than in the plant removal treatment (where $\sim 50 \%$ of biomass remained), depending upon the relative consumption rates of stipes versus fronds.

In each block, 2 replicate plots were randomly assigned to each of the 3 treatments in a randomized block design with replication within blocks. The treatments were applied on 12 July. As the front advanced, kelp plants or fronds were removed as required (2 to 3 times) to maintain the manipulation within a belt that extended at least $1 \mathrm{~m}$ into the kelp bed (i.e. in advance of the front) in the respective plots.

Urchin density and front advance. We monitored the rate of advance of the front and the density of urchins for $1 \mathrm{wk}$ (5 to 12 July) before the start of the experiment. Once the treatments were applied, we monitored the front at $4 \mathrm{~d}$ intervals for $24 \mathrm{~d}$ (12 July to 5 August) and then for an additional $21 \mathrm{~d}$ (5 to 25 August) after the experiment was terminated and the fences removed. To measure the advance of the urchin front, a linear series of benchmarks was established by anchoring numbered stainless-steel eyebolts at $2 \mathrm{~m}$ intervals in the barrens $\sim 1 \mathrm{~m}$ behind the leading edge of the front (and roughly perpendicular to the fences) using marine epoxy (Z-Spar A-788 Splash zone compound) (Fig. 2). On each sampling date, we used a plastic tape to measure ( $1 \mathrm{~cm}$ accuracy) the distance of the leading edge of the front (at the plot center) to each of the 2 benchmarks delimiting a plot. These 2 measures were then converted, by triangulation, into a perpendicular distance between the front and the $2 \mathrm{~m}$ line connecting the benchmarks.
On each sampling date, we measured urchin density along a $0.5 \mathrm{~m}$ wide belt transect centrally positioned in each plot and extending perpendicular to the kelpbarrens interface, from $1 \mathrm{~m}$ into the kelp bed to $3 \mathrm{~m}$ into the barrens. Urchins in the barrens behind the leading edge of the front were counted in a video transect recorded by a diver swimming along the transect from the edge of the kelp bed into the barrens. A $0.75 \mathrm{~m}$ wand maintained the camera at a fixed distance above bottom. A $0.25 \mathrm{~m}^{2}$ quadrat positioned at the leading edge of the front extending toward the barrens was included in each video as spatial reference. Video sequences were transformed into still images using video stitching software (PanoraGen.DV V1.0, www. fml-home.de/panoragen). The dimension of the reference quadrat was measured using image processing software (ImageJ, http://rsb.info.nih.gov/ij/) and a linear series of 5 contiguous $0.25 \mathrm{~m}^{2}$ quadrats was juxtaposed with the reference quadrat, forming a $0.5 \times$ $2.5 \mathrm{~m}$ belt extending from the leading edge of the front into the barrens. Urchins were counted in each of those digital quadrats with the aid of digital magnification and image enhancement software (Photoshop v.9.0, Adobe). Urchins were manually counted by divers when density could not be resolved using video: in the 2 quadrats in the kelp bed (where urchins were obscured by the canopy) and the one at the leading edge of the front (where high density required manually dissembling the front to attain reliable counts). We designated the position of the kelp-barrens interface (leading edge of the front) as 0 , negative values indicating a distance into the kelp bed (inshore direction) and positive values a distance into the barrens (offshore).

Kelp density and biomass. The density of each kelp species (Laminaria longicruris and L. digitata) was estimated in each plot when the treatments were applied on 12 July and the proportion of L. longicruris was calculated for each plot. We counted plants having a total length greater than $0.25 \mathrm{~m}$ in 2 contiguous $1 \times$ $1 \mathrm{~m}$ quadrats centrally positioned in the plot and extending from the kelp-barrens interface (i.e. leading edge of the urchin front) into the kelp bed. In plots assigned to the plant removal treatment, plants removed from the 2 quadrats were bagged and brought back to shore. These were sorted by species for each plot and drained fresh weight of whole plants and that of fronds only were separately measured on a spring scale (25 g accuracy). Plants removed from outside of the quadrats (in a $\sim 0.5 \mathrm{~m}$ strip to either side) as part of the manipulations also were bagged and removed from the study site. In plots assigned to the frond removal treatment, all fronds were bagged and removed from the site. We estimated the biomass of kelp (pooled over species) in each plot from the density of plants using a regression equation based on plants 
weighed and counted in the plant removal plots. As the fronts advanced, the 2 kelp removal treatments were re-applied ahead of the front in each replicate plot, and kelp density measured in a third contiguous $1 \times$ $1 \mathrm{~m}$ quadrat in all plots between 16 and 28 July.

Urchin size and weight. To measure the size-frequency distribution of urchins and to obtain a size-toweight relationship at the leading edge of the front and at 1,5 and $100 \mathrm{~m}$ (25 $\mathrm{m}$ depth), urchins were sampled in 5 to 10 haphazardly placed quadrats at each location ( $\mathrm{n}=106,74,62$ and 102 individuals respectively) on 9 August 2005. Test diameter was measured using vernier calipers (1 mm accuracy). Subsamples of 20 urchins each from the front and $1 \mathrm{~m}$ behind the leading edge of the front were pooled to establish a relationship between urchin test diameter and wet body weight. We used the size-to-weight relationship to convert diameter to urchin biomass and divided the total biomass by the number of urchins collected at the leading edge of the front, and in the barrens $1 \mathrm{~m}$ behind the front, to estimate the mean weight of individual urchins in each stratum.

Grazing rate. By multiplying the width of each plot $(2 \mathrm{~m})$ by the distance traveled by the front over the experiment, we obtained the total area grazed by urchins. We then multiplied this area by the estimated kelp biomass $\left(\mathrm{kg} \mathrm{m}^{-2}\right)$ in each plot to obtain the total biomass of kelp removed by the front. To estimate the biomass of kelp eaten $\mathrm{g}^{-1}$ urchin, we divided the total biomass removed from each plot by the respective urchin biomass in the effective front (the band over which urchins participate in the destructive grazing), and divided by $24 \mathrm{~d}$ to obtain daily grazing rates.

To estimate the biomass of urchins across the effective width of the front, we multiplied the mean number of urchins (during the experiment) in a $0.5 \mathrm{~m}$ wide belt extending $0.5 \mathrm{~m}$ into the kelp bed to $1 \mathrm{~m}$ into the barrens by the estimated mean individual weight of urchins at the leading edge of the front, and multiplied the number of urchins in the extension of that belt from 1 to $2 \mathrm{~m}$ into the barrens by the mean individual weight estimated for urchins $1 \mathrm{~m}$ behind the front. These 2 biomass values were then summed to obtain the total biomass in a belt extending $0.5 \mathrm{~m}$ into the kelp bed and $2 \mathrm{~m}$ into the barrens.

Statistical analysis. To detect differences between plots or experimental blocks in kelp density, proportion of each kelp species, or urchin density at the leading edge of the front at the start of the experiment (when treatments were applied), we used mixedmodel analysis of variance (ANOVA) with 'Treatment' as a fixed factor (3 levels) and 'Block' as a random factor (4 levels).

To test for an effect of treatment on urchin density at the leading edge of the front $\left(0.25 \mathrm{~m}^{2}\right.$ quadrat at 0 to
$0.5 \mathrm{~m}$ ), we used repeated-measures ANOVA with Treatment as a fixed factor, Block as a random factor, and sampling date 'Time' as the repeated factor. This was done independently for dates before $(\mathrm{n}=2$ dates), during $(\mathrm{n}=6$ dates) and after $(\mathrm{n}=2$ dates) the experiment. Mauchly's sphericity test (Winer et al. 1991) was non-significant $(p>0.05)$ for the analysis during the experiment. Tukey's HSD test was used to compare levels of Treatment.

To test for an effect of wave action on urchin density at the leading edge of the front $(0$ to $0.5 \mathrm{~m})$, we used analysis of covariance (ANCOVA) with significant wave height ( $\mathrm{SWH}$, the mean of the largest one third of waves measured) recorded over the previous $48 \mathrm{~h}$ as the covariate and Treatment as a fixed factor. The homogeneity of slope assumption was tested and, if violated $(p \leq 0.20)$, differences in least-square means between treatment levels were tested at the first, second, and third quartile of SWH (25th, 50th and 75th percentiles of SWH) using Tukey's HSD (Littell et al. 2002). Wave data were retrieved from a meteorological buoy (www.meds-sdmm.dfo-mpo.gc.ca) located at the mouth of Halifax Harbour (Buoy ID C44258, $44^{\circ} 30^{\prime} \mathrm{N}$, $\left.63^{\circ} 24^{\prime} \mathrm{W}\right) 11.9 \mathrm{~km}$ from our study site. The buoy is subject to a similar level of wave exposure as our study site, and SWH from this buoy has previously been correlated to flow regimes at a site located more than $35 \mathrm{~km}$ from the buoy (Schmidt \& Scheibling 2005).

To determine the effective width of the grazing front (i.e. those urchins participating in destructive grazing of the kelp bed), we used multiple regression to relate the distance of front advance over $24 \mathrm{~d}$ (over the experimental period) to both urchin density and kelp biomass in plots of the control and plant removal treatments. (We excluded the frond removal treatment from analysis because removing only fronds might differentially affect behavior of the front compared to a reduction in whole plant biomass.) Urchin density for each plot was calculated by counting the total number of urchins in a linear series of contiguous $0.25 \mathrm{~m}^{2}$ quadrats along a $0.5 \mathrm{~m}$ wide belt transect of increasing length (see earlier subsection 'Urchin density and front advance') and averaged over 7 sampling dates (12 July to 5 August). The initial transect consisted of the first quadrat into the kelp bed ( -0.5 to $0 \mathrm{~m})$. The second quadrat into the kelp bed ( -1 to $-0.5 \mathrm{~m}$ ) was excluded as a negligible number of urchins were present. We then increased the transect length by $0.5 \mathrm{~m}$ increments to $3 \mathrm{~m}$ into the barrens, giving 7 measures of urchin density across the front: -0.5 to $0,-0.5$ to $0.5,-0.5$ to 1 , -0.5 to $1.5,-0.5$ to $2,-0.5$ to 2.5 and -0.5 to $3 \mathrm{~m}$. A coefficient of determination $\left(\mathrm{r}^{2}\right)$ for the regression was calculated for each transect length with either urchin density as the only independent variable or a combination of urchin density, kelp biomass, and their interaction. 
A stepwise selection procedure was used and parameters were entered $(p \leq 0.05)$ in or removed $(p \geq 0.10)$ from the model according to their significance (Draper \& Smith 1998). Linearity was assessed by plotting the residuals. Standardized residuals were calculated to detect possible outliers ( $>3$ standard deviations from the mean of the residuals: Draper \& Smith 1998), but none were found and all data were included in the analysis.

We used a mixed-model ANOVA to test the effect of treatment on the total distance advanced by the front over the $24 \mathrm{~d}$ experiment. We did not detect a significant treatment effect $\left(F_{2,18}=0.23, \mathrm{p}=0.798\right)$ and therefore re-analyzed the data using ANCOVA with urchin density over the effective width of the front in each plot (in the -0.5 to $2 \mathrm{~m}$ transect), averaged over all sampling dates, as a covariate. We removed block from the analysis to increase the number of data points in each regression. The homogeneity of slope assumption was tested, and if violated ( $p \leq 0.20)$, differences in leastsquare means between treatment levels were tested at the first, second, and third quartile of urchin density using Tukey's HSD test (Littell et al. 2002).

We used multiple regression to determine the effects of kelp and urchin density on grazing rates of urchins. We used the total biomass of kelp grazed in a plot over the $24 \mathrm{~d}$ experiment (see earlier subsection 'Grazing rate') for plots assigned to the control treatment only.

All statistical analyses were done using SAS 9.0 (SAS Institute). Where applicable, the homoscedasticity assumption was tested ( $\alpha=0.05)$ using Cochran's $C$-test (Winer et al. 1991) and was met in each case except for gonad index and the proportion of Laminaria longicruris, which were transformed $(\log X$ and $\arcsin \sqrt{ } X$ respectively) prior to the analysis to homogenize variances. In mixed-model ANOVA, interactions with random terms were removed from the analysis when highly non-significant ( $p>0.20$ ) (Winer et al. 1991).

\section{RESULTS}

\section{Kelp density and biomass}

At the start of the experiment (12 July), no significant difference was detected in kelp density between Treatments $\left(F_{2,18}=0.05, \mathrm{p}=0.952\right)$ or Blocks $\left(F_{3,18}=2.91, \mathrm{p}=\right.$ $0.063)$, and there was no significant interaction $\left(F_{6,12}=\right.$ $0.73, \mathrm{p}=0.638)$. Mean density over all treatments was 18.0 plants $\mathrm{m}^{-2}( \pm 6.57 \mathrm{SD}, \mathrm{n}=24)$. Kelp biomass $(K, \mathrm{~kg}$ $\mathrm{m}^{-2}$ ) was regressed against kelp density $\left(P\right.$, plants $\left.\mathrm{m}^{-2}\right)$ in each plot, and the resulting equation $(K=0.2269 P+$ $1.2164)$ provided a good fit to the data $\left(r^{2}=0.78\right)$ over the observed range in density ( 8 to 35 plants $\mathrm{m}^{-2}$ ). Laminaria longicruris accounted for $55 \%( \pm 16 \%)$ of kelps; the remainders were $L$. digitata. This proportion did not vary significantly between Treatments $\left(F_{2,6}=0.71\right.$, $\mathrm{p}=0.528)$ or Blocks $\left(F_{3,12}=1.05, \mathrm{p}=0.405\right)$, and there was no significant interaction $\left(F_{6,12}=2.03, \mathrm{p}=0.139\right)$. Stipe biomass represented $\sim 40 \%$ of frond biomass (and $29 \%$ of whole plant biomass) for both species combined. Thus, biomass in plant removal plots was $\sim 50 \%$ of that in control plots, and biomass in frond removal plots was $\sim 29 \%$ of that in control plots.

\section{Urchin size and weight}

Size-frequency distributions of Strongylocentrotus drobachiensis at the leading edge of the front and at 1, 5 and $100 \mathrm{~m}$ into the barrens indicate that the front was mainly composed of large individuals and that size decreases with increasing distance from the front, particularly in the deeper water (25 $\mathrm{m}$ depth) furthest away (100 m; Fig. 3). No difference was detected in the wet weight $(W, \mathrm{~g})$ to test diameter $(D, \mathrm{~mm})$ relationship between urchins at the leading edge of the front and $1 \mathrm{~m}$ behind it (ANCOVA: $F_{1,37}=0.982 ; \mathrm{p}=$ $0.328)$. Therefore we pooled data from both strata and the resulting regression provided a strong fit ( $W=$ $\left.0.001 D^{2.7793}, \mathrm{r}^{2}=0.97\right)$. This translates into a mean weight of $49.2 \mathrm{~g}( \pm 15.9 \mathrm{SD}, \mathrm{n}=106)$ and of $44.8 \mathrm{~g}$ $( \pm 18.3, \mathrm{n}=74)$ for urchins at the leading edge and $1 \mathrm{~m}$ from the front respectively.

\section{Urchin density}

The density profile of Strongylocentrotus droebachiensis across the front, during the experiment is typical of urchin grazing fronts: density increased sharply from the kelp bed to a peak at the leading edge of the front, and decreased gradually along the trailing edge, leveling off between 1 and $3 \mathrm{~m}$ into the barrens (Fig. 4). Density at the leading edge of the front averaged 73.1 urchins $0.25 \mathrm{~m}^{-2}( \pm 23.2 \mathrm{SD}, \mathrm{n}=48)$ before the experiment, and was similar among plots designated for the 3 treatments (Fig. 5, Table 1). Initial densities did not vary significantly between the 2 sampling dates but did vary between blocks (Table 1). During the experiment, the repeated factor Time was significant, and both Treatment and Block had a significant effect on urchin density (Table 1). Urchin density at the leading edge of the front averaged $74.9( \pm 23.1$ SD) urchins $0.25 \mathrm{~m}^{-2}$ in the control, and $54.3( \pm 20.4)$ and 39.4 $( \pm 12.1)$ urchins $0.25 \mathrm{~m}^{-2}$ in the plant and frond removal treatments respectively. Multiple comparisons indicate that all 3 treatments differed significantly. Differences in urchin density between treatment plots disappeared after the experiment ended and fences were removed 

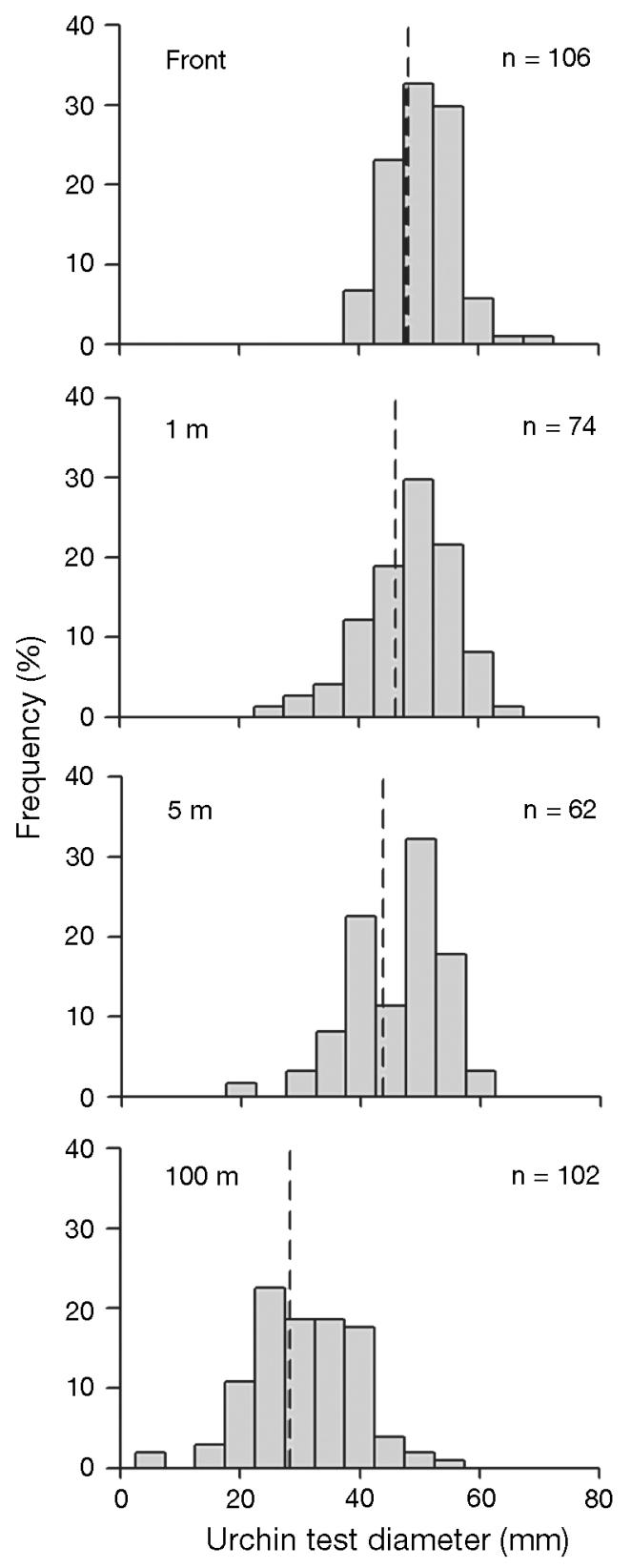

Fig. 3. Strongylocentrotus droebachiensis. Size-frequency distribution of test diameter $(\mathrm{mm})$ of sea urchins at leading edge of the front and at 1,5 and $100 \mathrm{~m}$ behind the front. Dashed vertical lines indicate mean test diameter

(Table 1). Differences between blocks and sampling date were also not significant after the experiment (Table 1).

Wide variations in urchin density at the leading edge of the front were observed throughout the experiment, particularly in the control and plant removal treatment (Fig. 5). To determine how much of this variation could be explained by wave action, we related urchin density at the leading edge of the front in each treatment

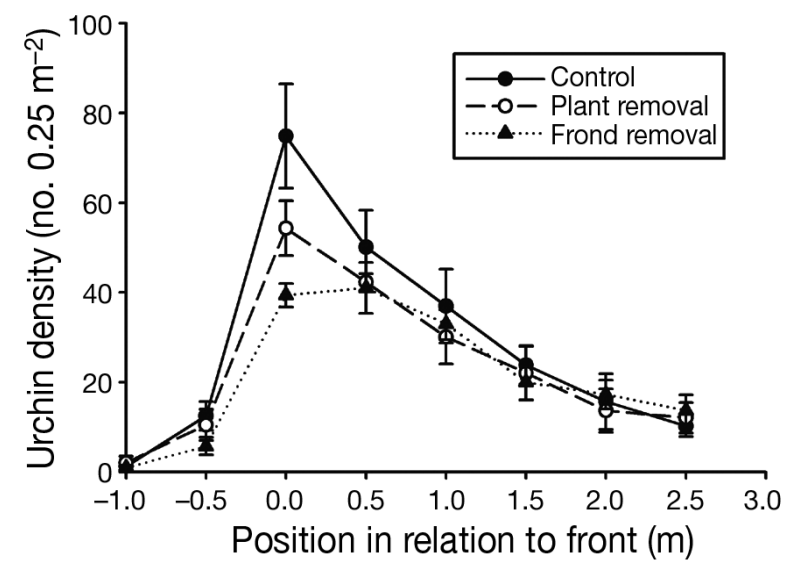

Fig. 4. Strongylocentrotus droebachiensis. Mean $( \pm \mathrm{SD}, \mathrm{n}=48)$ density profile of front of sea urchins in plots assigned to each of the 3 treatments over the $24 \mathrm{~d}$ experiment. Leading edge of the front is located at $0 \mathrm{~m}$. Negative values indicate distances into kelp bed, positive values are toward the barrens

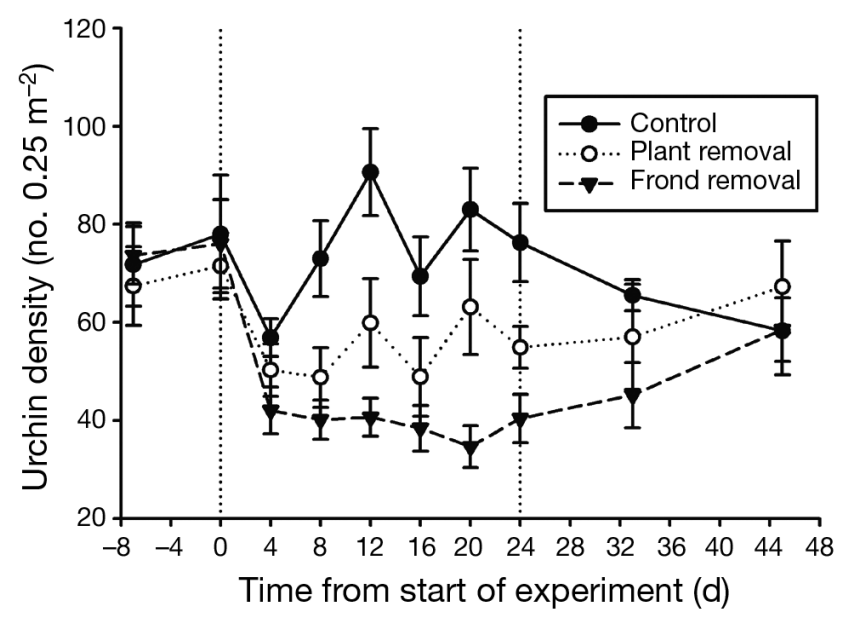

Fig. 5. Strongylocentrotus droebachiensis. Mean density $( \pm \mathrm{SE}, \mathrm{n}=8)$ at leading edge of the front for each treatment before, during and after $24 \mathrm{~d}$ experiment. Dotted vertical lines delineate experimental period (Days 0 to 24)

and at each sampling date to significant wave height (SWH) during the previous $48 \mathrm{~h}$ (Fig. 6). With all treatments included, the data did not meet the homogeneity of slope assumption (Table 2). Urchin density at the first and second quartile of SWH was greater in control than in plant removal plots, which in turn had a greater density than frond removal plots. At the third quartile of $\mathrm{SWH}$, urchin density was also greater in control plots, but did not differ between frond and plant removal plots (Table 2). Removing the frond treatment from the analysis resulted in homogeneous slopes $\left(F_{1,8}=1.41, \mathrm{p}=0.269\right)$. This model indicated a significant effect of both treatment and SWH (Table 2): urchin density was greatest in control plots and decreased with SWH, especially in control plots. 
Table 1. Strongylocentrotus droebachiensis. Repeated-measures ANOVA of effect Treatment (3 levels: control, 50\% plant removal, 100\% frond removal) and Block on density of sea urchins (no. $0.25 \mathrm{~m}^{-2}$ ) at leading edge of the front before, during and after a $24 \mathrm{~d}$ experiment. Boldface values indicate significance at $\mathrm{p} \leq 0.05$. For within-subject effects, Time and Time $\times$ Treatment were tested against pooled Time $\times$ Block MS, Time $\times$ Treatment $\times$ Block MS and residual MS, and Time $\times$ Block was tested against pooled Time $\times$ Treatment $\times$ Block MS and residual MS. For between-subject effects, Treatment and Block were tested against pooled Treatment $\times$ Block MS and residual MS

\begin{tabular}{|c|c|c|c|c|}
\hline Source of variation & df & MS & $F$ & $\mathrm{p}$ \\
\hline \multicolumn{5}{|l|}{ Before } \\
\hline \multicolumn{5}{|l|}{ Within-subject effects } \\
\hline Time & 1 & 216.75 & 1.37 & 0.240 \\
\hline Time $\times$ Treatment & 2 & 15.06 & 0.81 & 0.624 \\
\hline Time $\times$ Block & 3 & 244.97 & 0.47 & 0.704 \\
\hline Time $\times$ Treatment $\times$ Block & 6 & 371.37 & 0.63 & 0.704 \\
\hline Residual & 12 & 589.33 & & \\
\hline \multicolumn{5}{|l|}{ Between-subject effects } \\
\hline Treatment & 2 & 155.90 & 0.31 & 0.741 \\
\hline Block & 3 & 1845.64 & 3.61 & 0.034 \\
\hline Treatment $\times$ Block & 6 & 433.53 & 0.79 & 0.596 \\
\hline Residual & 12 & 549.67 & & \\
\hline \multicolumn{5}{|l|}{ During } \\
\hline \multicolumn{5}{|l|}{ Within-subject effects } \\
\hline Time & 5 & 656.67 & 2.67 & 0.026 \\
\hline Time $\times$ Treatment & 10 & 386.25 & 1.57 & 0.125 \\
\hline Time $\times$ Block & 15 & 226.48 & 0.91 & 0.556 \\
\hline Time $\times$ Treatment $\times$ Block & 30 & 176.69 & 0.62 & 0.923 \\
\hline Residual & 60 & 285.03 & & \\
\hline \multicolumn{5}{|l|}{ Between-subject effects } \\
\hline Treatment & 2 & 15249.56 & 25.16 & $<0.001$ \\
\hline Block & 3 & 2582.17 & 4.26 & 0.019 \\
\hline Treatment $\times$ Block & 6 & 603.45 & 0.99 & 0.472 \\
\hline Residual & 12 & 607.53 & & \\
\hline \multicolumn{5}{|l|}{ After } \\
\hline \multicolumn{5}{|l|}{ Within-subject effects } \\
\hline Time & 1 & 357.52 & 1.99 & 0.087 \\
\hline Time $\times$ Treatment & 2 & 494.27 & 1.17 & 0.364 \\
\hline Time $\times$ Block & 3 & 9.58 & 0.02 & 0.994 \\
\hline Time $\times$ Treatment $\times$ Block & 6 & 289.91 & 0.67 & 0.675 \\
\hline Residual & 12 & 431.35 & & \\
\hline \multicolumn{5}{|l|}{ Between-subject effects } \\
\hline Treatment & 2 & 553.77 & 0.99 & 0.391 \\
\hline Block & 3 & 1411.47 & 2.52 & 0.090 \\
\hline Treatment $\times$ Block & 6 & 121.80 & 0.16 & 0.984 \\
\hline Residual & 12 & 778.35 & & \\
\hline
\end{tabular}

culated for each regression using either urchin density only or urchin density and kelp biomass as the independent variables (Fig. 8). Using the urchin density in the kelp bed only ( -0.5 to $0 \mathrm{~m}$ ) resulted in the lowest $\mathrm{r}^{2}$ value. Including the density of urchins at the leading edge of the front ( 0 to $0.5 \mathrm{~m}$ ) greatly increased $\mathrm{r}^{2}$. Sequential $0.5 \mathrm{~m}$ increments in transect length continued to increase $r^{2}$, but most of the increase occurred within the first $2 \mathrm{~m}$ into the barrens. A similar pattern was observed when kelp biomass was included in the model (Fig. 8).

Based on the results in Fig. 8, we used the number of urchins in a belt transect from -0.5 to $2 \mathrm{~m}$ into the barrens to obtain the effective front density $\left(U\right.$, no. urchins $\left.\mathrm{m}^{-2}\right)$. We used this density estimate and the biomass of kelp $\left(K, \mathrm{~kg} \mathrm{~m}^{-2}\right)$ in each plot (excluding the frond removal treatment) as well as the interaction between these 2 variables to predict the rate of advance of the urchin front $\left(F, \mathrm{~m}_{2} 4 \mathrm{~d}^{-1}\right)$ and to determine the effect of each variable on the rate of advance of the front. The interaction term was not significant ( $p>0.20$ ) and was removed from the analysis. This yielded the model: $F=-0.1895+0.0242 U-0.2771 K$. This model explained $75 \%$ of the variation observed in the distance traveled by the front over $24 \mathrm{~d}$. Front advance increased linearly with increasing urchin density and decreased with increasing kelp biomass (Fig. 9).

The total distance traveled by the front over $24 \mathrm{~d}$ averaged $2.27 \pm 0.21 \mathrm{~m}$ (mean $\pm \mathrm{SE}, \mathrm{n}=24$ ) and did not differ between treatments, but differed sig-

\section{Front advance and front width}

As the front advanced through the kelp bed, urchins at the leading edge climbed the stipes (Fig. 7a) weighing down fronds and consuming them (Fig. 7b), while trailing urchins consumed stipes and holdfasts, leaving encrusting coralline algae and sponges in the wake. To determine the width of the effective front, the total distance traveled by the front in each plot over the $24 \mathrm{~d}$ experiment was predicted using the urchin density in a belt transect starting $0.5 \mathrm{~m}$ into the kelp bed and extending from 0 to up to $3 \mathrm{~m}$ into the barrens. The coefficient of determination $\left(\mathrm{r}^{2}\right)$ of the model was cal- nificantly between blocks (Fig. 10, Table 3). To account for between-block variation, we used the density of urchins in the front $(-0.5$ to $2 \mathrm{~m})$ in each plot as a covariate and re-ran the analysis with treatment, urchin density and their interaction as sources of variation (Table 4). With all treatments included, slopes were significantly different $(\alpha=0.20)$ (Table 4, Fig. 11). Front advance was greater in frond and plant removal plots than in control plots for the first and second quartiles of urchin density, but did not differ for the third quartile (Table 4). Excluding the frond removal treatment resulted in homogeneous slopes $\left(F_{1,12}=1.67, \mathrm{p}=\right.$ 0.2203 ) and a significant effect of treatment and urchin 


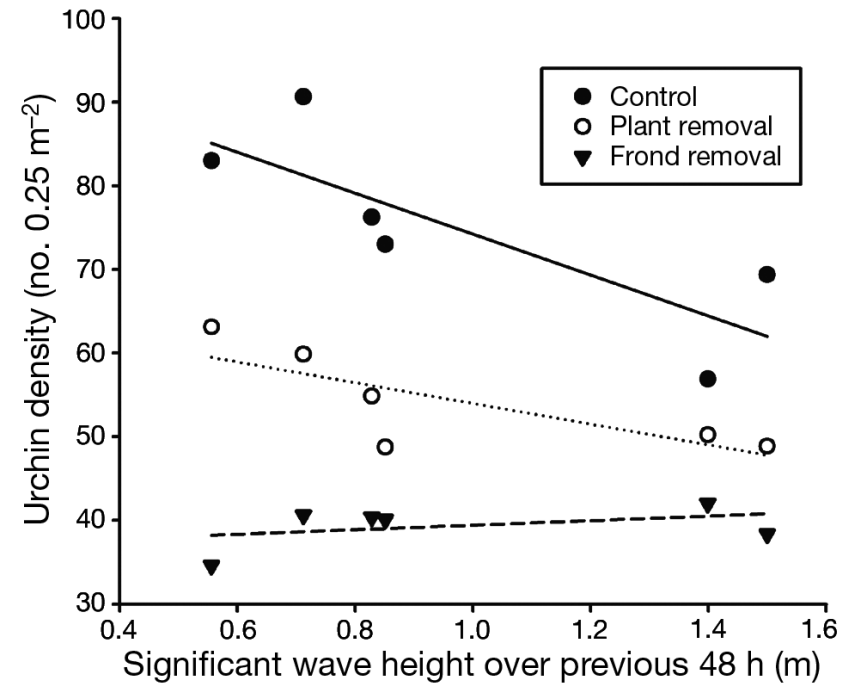

Fig. 6. Strongylocentrotus droebachiensis. Relationship between mean density at leading edge of the front and significant wave height recorded over the $48 \mathrm{~h}$ prior to sampling. Urchin density was averaged over 8 replicate plots. Lines represent regression equations for control plots (continuous line), kelp removal plots (dotted line) and frond removal plots (dashed line)

density (Table 4): rate of advance of the front increased with increasing urchin density and was greater in plant removal plots than in controls, when urchin density is accounted for (Fig. 11).

Table 2. Strongylocentrotus droebachiensis. ANCOVA of effect of all treatments (i.e. control, $50 \%$ plant removal, $100 \%$ frond removal) and of control and plant removal treatments only, and significant wave height (SWH) during previous $48 \mathrm{~h}$ on density of sea urchins (no. $0.25 \mathrm{~m}^{-2}$ ) at leading edge of the front. Urchin density was averaged over the 8 replicate plots for a given treatment and sampling date. Boldface values indicate significance at $\mathrm{p} \leq 0.05$ for interpretable effects only (i.e. not part of an interaction)

\begin{tabular}{|lrrrr|}
\hline Source of variation & df & MS & \multicolumn{1}{c|}{$F$} & \multicolumn{1}{c|}{$\mathrm{p}$} \\
\hline All treatments & & & & \\
$\quad$ Treatment & 2 & 661.03 & 23.80 & $<0.001$ \\
SWH & 1 & 286.18 & 10.30 & 0.007 \\
Treatment $\times$ SWH & 2 & 136.86 & 4.93 & $\mathbf{0 . 0 2 7}$ \\
Residual & 12 & 27.78 & & \\
Without frond removal treatment & & \\
Treatment & 1 & 1268.45 & 31.79 & $<\mathbf{0 . 0 0 1}$ \\
SWH & 1 & 500.58 & 12.55 & $\mathbf{0 . 0 0 6}$ \\
Residual & 9 & 39.90 & & \\
\hline
\end{tabular}
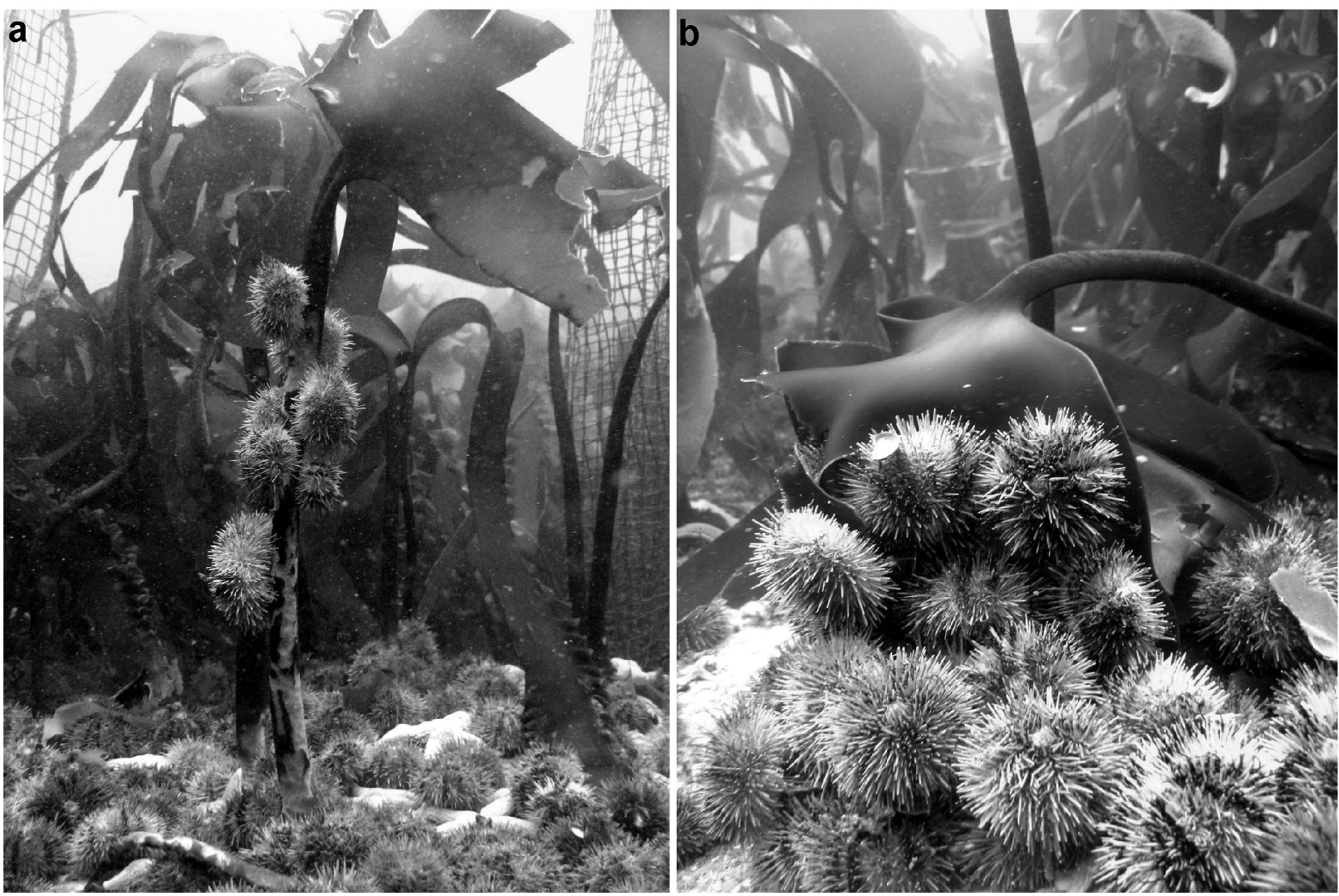

Fig. 7. Strongylocentrotus droebachiensis. Sea urchins (a) climbing a stipe of Laminaria digitata and (b) aggregating on and weighing down a frond of L. digitata 


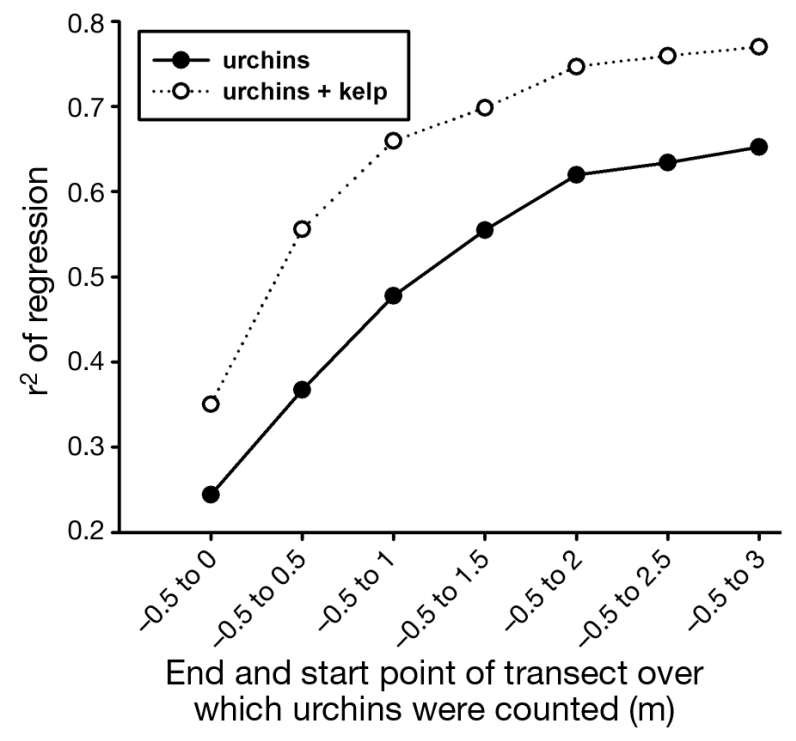

Fig. 8. Strongylocentrotus droebachiensis. Coefficient of determination $\left(\mathrm{r}^{2}\right)$ of multiple regression equations based on varying lengths of the belt transect over which density of sea urchins was calculated. Multiple regressions were done on the front advance over $24 \mathrm{~d}$ using urchin density either alone or coupled with kelp biomass as the predictive variables. Leading edge of front is located at $0 \mathrm{~m}$. Negative values indicate distances into kelp bed, positive values are toward the barrens. Frond removal plots were excluded from the analysis

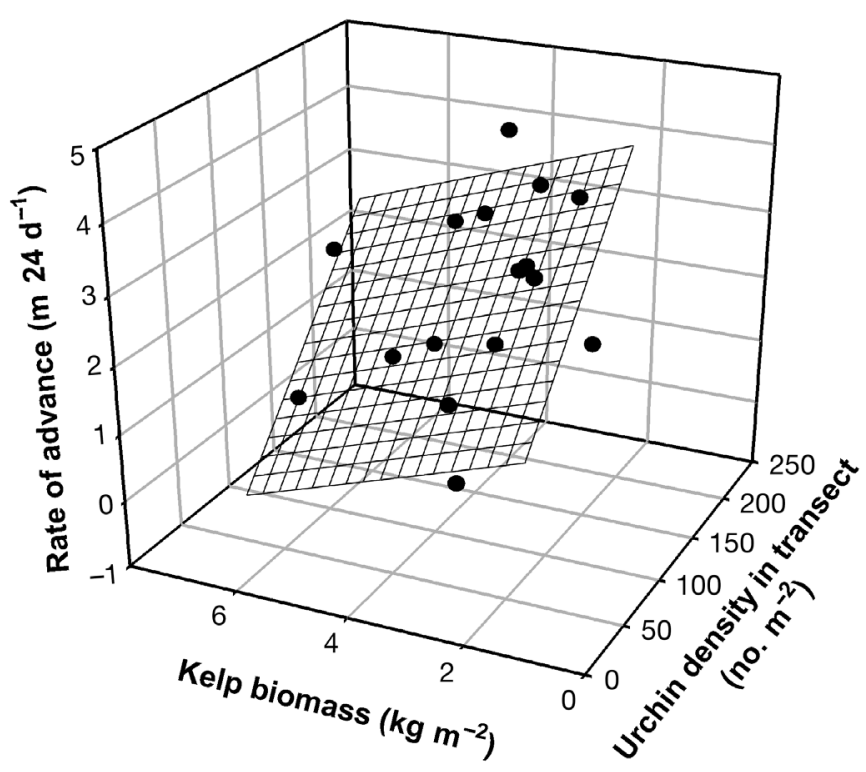

Fig. 9. Strongylocentrotus droebachiensis. Multiple regression of distance advanced by front of sea urchins over the $24 \mathrm{~d}$, with kelp biomass and urchin density as the independent variables. Urchin density was measured in a $0.5 \times$ $2.5 \mathrm{~m}$ transect (i.e. spanning the effective front) averaged over the 7 sampling dates. Each data point represents an experimental plot and the plane represents the regression equation

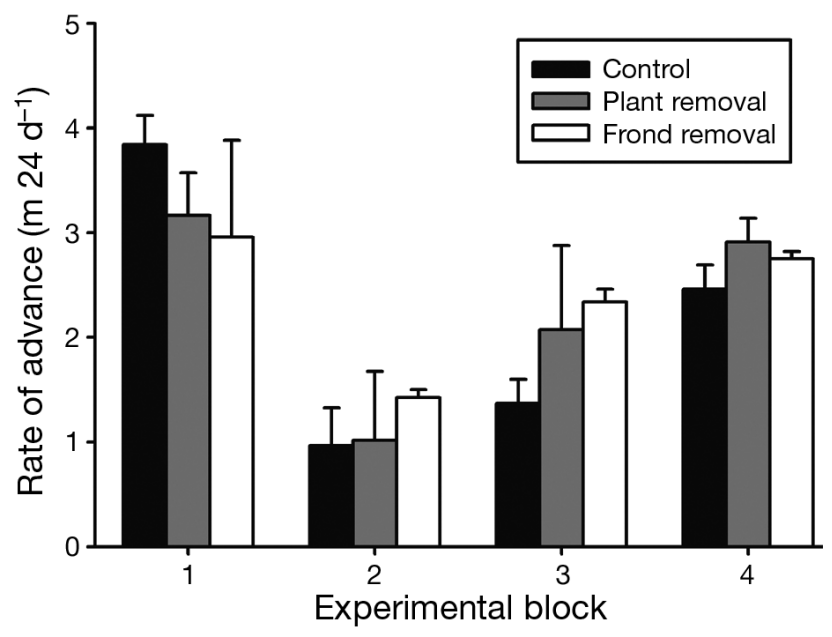

Fig. 10. Strongylocentrotus droebachiensis. Mean $(+\mathrm{SE}, \mathrm{n}=$ 2) distance advanced by front of sea urchins over the $24 \mathrm{~d}$ for each treatment (control, 50\% plant removal, 100\% frond removal) in each experimental block

\section{Grazing rates}

We use urchin biomass estimates (wet weight) to calculate an overall mean grazing rate for Strongylocentrotus droebachiensis of $0.027 \mathrm{~g}$ kelp $\mathrm{g}^{-1}$ urchin $\mathrm{d}^{-1}$ (range: 0.010 to $0.047 \mathrm{~g}$ kelp $\mathrm{g}^{-1}$ urchin $\mathrm{d}^{-1}$ ). In our experiment, individual grazing rates $\left(G, \mathrm{~g}\right.$ of kelp $\mathrm{g}^{-1}$ urchin $\mathrm{d}^{-1}$ ) increased with both increasing urchin density $\left(U\right.$, no. urchins $\left.\mathrm{m}^{-2}\right)$ and kelp biomass $(K, \mathrm{~kg}$ $\mathrm{m}^{-2}$ ) in control plots (multiple regression: $G=-0.027+$ $0.0004 U+0.0026 K, \mathrm{r}^{2}=0.88 ; \mathrm{p}_{\text {urchin }}=0.002 ; \mathrm{p}_{\text {kelp }}=$ $0.034)$.

\section{DISCUSSION}

\section{Urchin density}

Our experimental manipulation of the Laminaria spp. canopy had a direct effect on the density of Strongylocentrotus droebachiensis at the leading edge of the front. Urchin density decreased in plots where kelps were thinned by $50 \%$, or fronds were removed entirely, compared to unmanipulated control plots. This response appears to be related to available kelp biomass, which was highest in the control and lowest in the frond removal treatment. This suggests that urchin fronts disperse when food availability is low but form extremely dense aggregations (up to 500 urchins $\mathrm{m}^{-2}$ ) when food is readily available. Although aggregation of urchins in the presence of food is well documented (Garnick 1978, Vadas et al. 1986, Hagen \& Mann 1994), the level of aggregation 
Table 3. Strongylocentrotus droebachiensis. ANOVA of effect on treatment (3 levels, i.e. control, $50 \%$ plant removal, 100\% frond removal) and block on distance by sea urchin front (m) over $24 \mathrm{~d}$. Boldface values indicate significance at $\mathrm{p} \leq 0.05$. Treatment and Block were tested against pooled Treatment $x$ Block MS and Residual MS

\begin{tabular}{|lrcrr|}
\hline Source of variation & df & MS & \multicolumn{1}{c|}{$F$} & \multicolumn{1}{c|}{$\mathrm{p}$} \\
\hline Treatment & 2 & 0.09 & 0.23 & 0.798 \\
Block & 3 & 5.40 & 13.63 & $<\mathbf{0 . 0 0 1}$ \\
Treatment $\times$ Block & 6 & 0.36 & 0.86 & 0.548 \\
Residual & 12 & 0.42 & & \\
\hline
\end{tabular}

Table 4. Strongylocentrotus droebachiensis. ANCOVA of effect of all treatments; i.e. control, $50 \%$ plant removal, 100\% frond removal, and of control and plant removal treatments only, and urchin density (no. $\mathrm{m}^{-2}$ ) in $0.5 \times 2.5 \mathrm{~m}$ transect perpendicular to the front averaged over course of the experiment on the total advance of the front $(\mathrm{m})$ over $24 \mathrm{~d}$. Boldface values indicate significance at $p \leq 0.05$ for interpretable effects only (i.e. not part of an interaction)

\begin{tabular}{|lrrrr|}
\hline Source of variation & df & MS & $F$ & $\mathrm{p}$ \\
\hline All treatments & & & & \\
Treatment & 2 & 1.64 & 4.29 & 0.030 \\
Urchin density & 1 & 14.95 & 39.61 & $<0.001$ \\
Treatment $\times$ Urchin density & 2 & 0.97 & 2.54 & 0.106 \\
Residual & 18 & 0.38 & & \\
Without frond removal treatment & & & \\
Treatment & 1 & 2.81 & 8.33 & $\mathbf{0 . 0 1 3}$ \\
Urchin density & 1 & 14.43 & 42.86 & $<\mathbf{0 . 0 0 1}$ \\
Residual & 13 & 0.34 & & \\
\hline
\end{tabular}

has not previously been related to the amount of available food. Although the initial stimulus responsible for the formation of grazing fronts remains unclear (Bernstein et al. 1983, Vadas et al. 1986), our results suggest that aggregation is a response to a gradient in food availability (Scheibling et al. 1999). Food availability does not appear to explain differences in urchin density between experimental blocks, however, as neither the density nor composition of the kelp bed differed between blocks. Abiotic factors, such as bottom slope, rugosity, or large topographic features that modify flow may explain larger scale (between blocks) spatial variation in urchin abundance.

The density of Strongylocentrotus droebachiensis at the leading edge of the front also varied markedly through time, particularly in the control plots. The strong effect of significant wave height on urchin density suggests that dense aggregations disperse when wave action increases. This may be due to the 'whiplash effect' of kelp, which deters urchins in strong wave surge (Konar \& Estes 2003, Siddon \& Witman 2003) or limits their ability to climb stipes

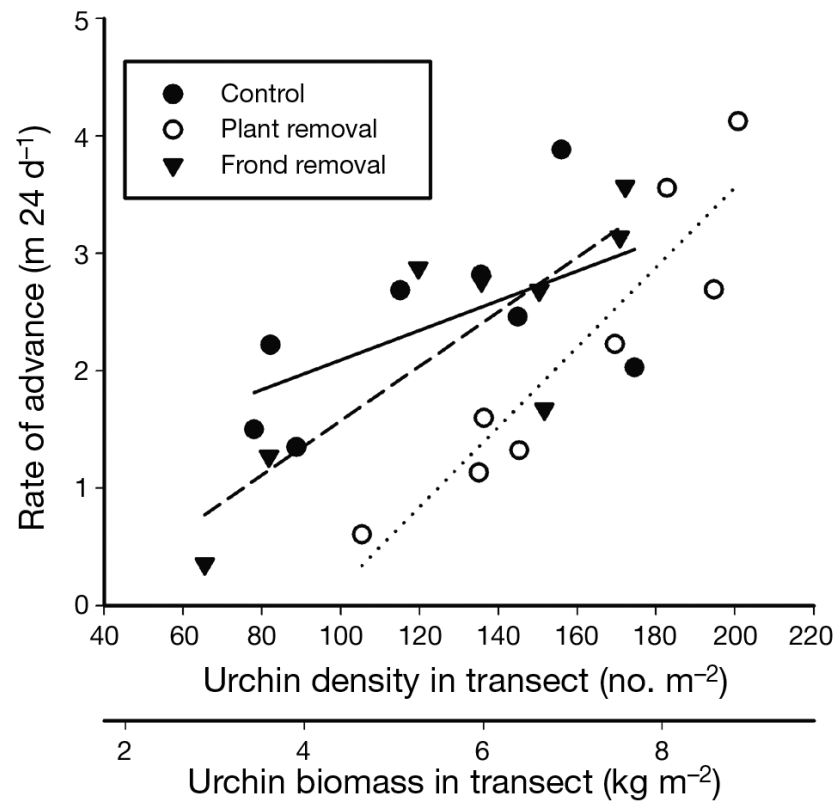

Fig. 11. Strongylocentrotus droebachiensis. Distance advanced by the front of sea urchins regressed against urchin density in a $0.5 \times 2.5 \mathrm{~m}$ transect (i.e. spanning the effective front) averaged over 7 sampling dates for each treatment: control (continuous line), 50\% plant removal (dotted line), 100\% frond removal plots (dashed line). Secondary $x$-axis indicates equivalent urchin biomass

(Velimirov \& Griffiths 1979). Also, 3-dimensional aggregations may be more vulnerable to strong wave action than 2-dimensional ones (Scheibling et al. 1999). Fronds appear to be particularly important in preventing urchins from feeding and aggregating in high wave conditions, as the slope of the relationship between urchin density and significant wave height was significantly smaller for the frond removal treatment than for the other 2 treatments. The swaying movement of the fronds in wave surge was probably more effective at preventing urchins from climbing onto kelp plants than the stipes alone, which are stiff and have little surface area, and hence much less drag than whole plants. Kawamata (1998) showed that movement and feeding activity of $S$. nudus decreases at water velocities above $0.4 \mathrm{~m} \mathrm{~s}^{-1}$ in a laboratory flume. In the field, wave action also has been shown to reduce the movement of $S$. droebachiensis at water velocities $\left(\sim 0.5 \mathrm{~m} \mathrm{~s}^{-1}\right)$ well below those that dislodge individuals (Siddon \& Witman 2003). This effect of wave action on urchin aggregation may be responsible for reductions in urchin density and concomitant decreases in the rate of advance of urchin fronts observed during fall and winter (Scheibling et al 1999, Gagnon et al. 2004), when frequent storms generate strong waves and heavy sea conditions. 


\section{Front advance}

Correlation between seasonal variation in urchin density and front advance has lead previous workers to hypothesize that the density (or biomass) of Strongylocentrotus droebachiensis determines the rate of front advance (Breen \& Mann 1976, Scheibling et al. 1999, Gagnon et al. 2004). Correlative data offer ambiguous evidence of a causal effect of urchin density, as other factors (e.g. temperature, wave action, or behavioral responses to predators) may explain some of the observed variation in front movement (Scheibling et al. 1999). However, because we concurrently recorded front movement over a broad range of urchin densities, these abiotic factors are unlikely to explain the differences we observed. Our results clearly indicate that the rate of advance of urchin fronts is affected by the density of urchins forming the front.

Previous studies have described fronts of Strongylocentrotus droebachiensis as dense bands of urchins about 1 and $2 \mathrm{~m}$ wide (Scheibling et al. 1999, Gagnon et al. 2004). However, the actual band width of urchins directly involved in destructive grazing has never been quantified. Our results show that it is not simply the urchins at the leading edge of the front that determine the rate of advance of the urchin front, but rather a broader belt extending from $0.5 \mathrm{~m}$ into the kelp bed to $2 \mathrm{~m}$ into the barrens. This suggests that urchins that are not directly in contact with kelp fronds also affect the collective advance of the front. Typically, urchins along the leading edge of the front consume kelp fronds and turf algae, but leave the stipes largely ungrazed (J. S. Lauzon-Guay pers. obs.). Thus, a large biomass of kelp stipes and holdfasts is available to urchins forming the trailing edge of the front. In our study, stipe biomass alone represented $40 \%$ of the biomass contained in fronds.

Contrary to our predictions, urchin fronts did not advance faster in plots with reduced kelp biomass; front advance was similar among all experimental treatments. As previously mentioned, urchins probably redistributed themselves according to food availability, resulting in high urchin densities in control plots and low densities in frond removal plots. Nonetheless, both multiple regression analysis and ANCOVA indicate that, for a given urchin density, high kelp biomass reduces the rate of advance of urchin fronts. This strongly suggests that the rate of advance of an urchin front is determined by individual consumption rates.

The redistribution of urchins between plots suggests that the fences (which extended only $0.5 \mathrm{~m}$ into the barrens beyond the edge of the kelp bed) did not prevent urchins from moving laterally along the front and into other plots. The fences had no apparent effect on urchin behaviour. We rarely observed urchins climbing fences, and the density and rate of advance of the front in control plots did not change before, during or after the experiment.

Previous studies have proposed a threshold level of biomass of Strongylocentrotus droebachiensis below which an urchin front does not destructively graze kelp (Breen \& Mann 1976, Scheibling et al. 1999, Gagnon et al. 2004). Given the average weight of an individual urchin in the front estimated in our study (49.2 g), the previously reported threshold for Nova Scotia (2 kg $\mathrm{m}^{-2}$; Breen \& Mann 1976, Scheibling et al. 1999) would represent 41 urchins $\mathrm{m}^{-2}$. At a higher threshold proposed for fronts in the northern Gulf of St. Lawrence ( $5 \mathrm{~kg} \mathrm{~m}^{-2}$ for a $1 \mathrm{~m}$ wide band; Gagnon et al. 2004), this estimate would increase to 102 urchins $\mathrm{m}^{-2}$. Front densities observed in our study were generally much higher than the proposed threshold values. Our regression equation predicts no advance of the front when urchin density in the $2.5 \mathrm{~m}$ wide band around the kelp bed-barrens interface (effective front) is below 31 to 65 urchins $\mathrm{m}^{-2}$ (equivalent to urchin biomass of 1.5 to $3.2 \mathrm{~kg} \mathrm{~m}^{-2}$ ) for kelp biomass of 2 to $5 \mathrm{~kg} \mathrm{~m}^{-2}$ respectively. The biomass estimates increase to 2.3 and $5.0 \mathrm{~kg} \mathrm{~m}^{-2}$ respectively, if only urchins in the first $1 \mathrm{~m}$ into the barrens are included; these are comparable to the range of values previously reported. However, these values result from extrapolation of our regression equation beyond the range of observations and the regression may not remain linear when front movement approaches zero. These results also indicate that a lower threshold is dependent on kelp biomass; more urchins are needed to consume a dense kelp bed than a sparse one (Scheibling et al. 1999). This alone could explain differences in threshold values reported for Atlantic Nova Scotia and the Gulf of St. Lawrence (Scheibling et al. 1999, Gagnon et al. 2004).

The mean feeding rate of urchins estimated in our

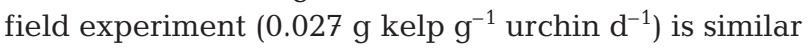
to values reported for Strongylocentrotus droebachiensis fed Laminaria ad libidum in laboratory experiments (e.g. Larson et al. 1980: 0.020 to $0.064 \mathrm{~g} \mathrm{kelp} \mathrm{g}^{-1}$ urchin $\mathrm{d}^{-1}$; Minor \& Scheibling 1997: 0.033 to $0.055 \mathrm{~g}$ kelp $\mathrm{g}^{-1}$ urchin $\mathrm{d}^{-1}$; see also Scheibling \& Hatcher 2001 for review). Our estimates also are similar to those recorded in the field for an active feeding front in southwestern Nova Scotia (0.04 $\mathrm{g}_{\text {kelp g }}{ }^{-1}$ urchin $\mathrm{d}^{-1}$; Scheibling et al. 1999). In our experiment, individual feeding rates tended to increase with both increasing urchin density and kelp biomass in control plots. An increase in feeding rate with increasing urchin density suggests aggregative feeding facilitation. Although this is more common in predatory animals (e.g. schooling fish; Grunbaum 1998), it also has been observed in herbivores (Inouye \& Johnson 2005). At high urchin 
density, we might expect that interference competition negatively effects feeding rate. However, this seems to be outweighed by increased food availability when urchins feed in an aggregation. Growth and reproductive output are consistently greater for urchins in feeding fronts than in adjacent barrens (Meidel \& Scheibling 1998).

The fact that we did not observe an increased rate of advance of the front in the frond removal treatment compared to the control must be interpreted cautiously. The scale at which a change in kelp biomass occurs is likely to have a profound effect on the behaviour of urchins. In our experiment, urchins in plots with reduced kelp biomass (such as those in the frond removal treatment) redistributed themselves to adjacent plots with greater food availability. Major kelp defoliation events, such as those resulting from outbreaks of the invasive bryozoan Membranipora membranacea, reduce kelp biomass at larger scales (100s of meters to kilometers) than those addressed in our experiment (Dixon et al. 1981, Scheibling et al. 1999). Thus, urchins are unlikely to disperse when encountering a defoliated kelp bed. Foraging movements of Strongylocentrotus droebachiensis are generally in the order of 0.5 to $3.0 \mathrm{~m} \mathrm{~d}^{-1}$ (Propp 1977, Garnick 1978, Lauzon-Guay et al. 2006), which limits the range of migration. Thus, there is likely to be a synergistic effect of low kelp biomass (e.g. due to outbreaks of $M$. membranacea) and high urchin density on the rate of destructive grazing (Scheibling et al. 1999).

Our results show that destructive grazing aggregations of Strongylocentrotus droebachiensis are dynamic and respond to both biotic and abiotic factors. The ability of urchins to redistribute themselves along a front according to food availability suggests that behavioural adjustments maintain the linear pattern of the front. In our study, we observed that urchins along the front dispersed in apparently random directions when encountering defoliated plots (frond removal treatment) rather than advancing through these areas as a cohesive group. This suggests that urchins move randomly while foraging (Lauzon-Guay et al. 2006) until they encounter a rich food patch and stop to graze, rather than direct their movement toward the kelp bed. Although previous work has shown that urchins can detect food and move toward it (Larson et al. 1980, Mann et al. 1984), whether they can discriminate patches with different amount of food and direct their movement toward the highest quality food patch is unclear.

The reduction in urchin density observed in low kelp biomass plots also suggests that these aggregations are an emergent pattern resulting from individual behaviours rather than a true social aggregation (Parrish \& Edelstein-Keshet 1999). Previous work has suggested specific mechanisms leading to the initial formation of fronts (e.g. predator avoidance), while their persistence has been associated with food consumption (Mann 1985). Although our results suggest that aggregations do provide feeding facilitation, they also suggest that urchins do not form associative aggregations (Lauzon-Guay et al. 2006). Rather, these aggregations are purely a result of food availability. Whether this is the case for other animals that form fronts is unknown, but theoretical work might prove useful in exploring mechanisms that can cause such patterns to emerge and persist.

Acknowledgements. We thank J. Lindley, D. Lyons, M. Saunders, P. Gagnon, A. Schmidt, A. Comeau, A. Pinder and D. Knip for their assistance in the field. We are also grateful to $\mathrm{M}$. Barbeau and 4 anonymous reviewers for providing comments on the manuscript. This research was funded by a scholarship from the Fond Québécois pour la Recherche sur la Nature et les Technologies to J.S.L.-G. and a grant from the Natural Sciences and Engineering Research Council of Canada to R.E.S.

\section{LITERATURE CITED}

Bernstein BB, Schroeter SC, Mann KH (1983) Sea urchin (Strongylocentrotus droebachiensis) aggregating behaviour investigated by a subtidal multifactorial experiment. Can J Fish Aquat Sci 40:1975-1986

Breen PA, Mann KH (1976) Changing lobster abundance and the destruction of kelp beds by sea urchins. Mar Biol 34: $137-142$

Chapman ARO, Johnson CR (1990) Disturbance and organization of macroalgal assemblages in the Northwest Atlantic. Hydrobiologia 192:77-121

Clua E, Grosvalet F (2001) Mixed-species feeding aggregation of dolphins, large tunas and seabirds in the Azores. Aquat Living Resour 14:11-18

Collett M, Despland E, Simpson SJ, Krakauer DC (1998) Spatial scales of desert locust gregarization. Proc Natl Acad Sci USA 95:13052-13055

Dixon J, Schroeter SC, Kastendiek J (1981) Effects of the encrusting bryozoan, Membranipora membranacea, on the loss of blades and fronds by the giant kelp, Macrocystis pyrifera (Laminariales). J Phycol 17:341-345

Draper NR, Smith H (1998) Applied regression analysis, 3rd edn. Wiley-Interscience, New York

Foreman RE (1977) Benthic community modification and recovery following intensive grazing by Strongylocentrotus droebachiensis. Helgol Wiss Meeresunters 30:468-484

Gagnon P, Himmelman JH, Johnson LE (2004) Temporal variation in community interfaces: kelp-bed boundary dynamics adjacent to persistent urchin barrens. Mar Biol 144:1191-1203

Garnick E (1978) Behavioral ecology of Strongylocentrotus doebachiensis (Müller) (Echinodermata: Echinoidea): aggregating behavior and chemotaxis. Oecologia 37:77-84

Grunbaum D (1998) Schooling as a strategy for taxis in a noisy environment. Evol Ecol 12:503-522

Hagen NT (1987) Sea urchin outbreaks and nematode epizootics in Vestfjorden, northern Norway. Sarsia 72: 213-229

Hagen NT, Mann KH (1994) Experimental analysis of factors influencing the aggregating behaviour of the green sea 
urchin Strongylocentrotus droebachiensis (Mueller). J Exp Mar Biol Ecol 176:107-126

Harris LG, Tyrrell MC (2001) Changing community states in the Gulf of Maine: synergism between invaders, overfishing and climate change. Biol Invasions 3:9-21

Hjörleifsson E, Kaasa O, Gunnarsson K (1995) Grazing of kelp by green sea urchin in Eyjafjoerdur, North Iceland. In: Skjodal HR, Hopkins C, Erikstad KE, Leinaas HP (eds) Ecology of fjords and coastal wates. Elsevier Science, Amsterdam, p 593-597

Inouye BD, Johnson DM (2005) Larval aggregation affects feeding rate in Chlosyne poecile (Lepidoptera: Nymphalidae). Fla Entomol 88:246-347

Jensen KH, Larsson P (2002) Predator evasion in Daphnia: the adaptive value of aggregation associated with attack abatement. Oecologia 132:461-467

Kawamata S (1998) Effect of wave-induced oscillatory flow on grazing by a subtidal sea urchin Strongylocentrotus nudus (A. Agassiz). J Exp Mar Biol Ecol 224:31-48

Konar B, Estes JA (2003) The stability of boundary regions between kelp beds and deforested areas. Ecology 84: $174-185$

Larson BR, Vadas RL, Keser M (1980) Feeding and nutritional ecology of the sea urchin Strongylocentrotus drobachiensis in Maine, USA. Mar Biol 59:49-62

Lauzon-Guay JS, Scheibling RE, Barbeau MA (2006) Movement patterns in the green sea urchin, Strongylocentrotus droebachiensis. J Mar Biol Assoc UK 86:167-174

Littell RC, Stroup WW, Freund R (2002) SAS for linear models, 4 th edn. John Wiley \& Sons, New York

Mann KH (1982) Ecology of coastal waters, a systems approach. Blackwell Scientific Publications, Oxford

Mann KH (1985) Invertebrate behaviour and the structure of marine benthic communities. In: Sibley RM, Smith RH (eds) Behavioural ecology. Blackwell Scientific, Oxford, p $227-246$

Mann KH, Wright JLC, Welsford BE, Hatfield E (1984) Responses of the sea urchin Strongylocentrotus droebachiensis (O.F. Mueller) to water-borne stimuli from potential predators and potential food algae. J Exp Mar Biol Ecol 79:233-244

Meidel SK, Scheibling RE (1998) Annual reproductive cycle of the green sea urchin, Strongylocentrotus droebachiensis, in differing habitats in Nova Scotia, Canada. Mar Biol 131: $461-478$

Minor MA, Scheibling RE (1997) Effects of food ration and feeding regime on growth and reproduction of the sea urchin Strongylocentrotus droebachiensis. Mar Biol 129: 159-167

Editorial responsibility: John Lawrence (Contributing Editor), Tampa, Florida, USA
Parrish JK, Edelstein-Keshet L (1999) Complexity, pattern, and evolutionary trade-offs in animal aggregation. Science 284:99-101

Propp MV (1977) Ecology of the sea urchin Strongylocentrotus droebachiensis of the Barents Sea: metabolism and regulation of abundance. Sov J Mar Biol 3:27-37

Rose CD, Sharp WC, Kenworthy WJ, Hunt JH and 6 others (1999) Overgrazing of a large seagrass bed by the sea urchin Lytechinus variegatus in Outer Florida Bay. Mar Ecol Prog Ser 190:211-222

Scheibling RE, Hatcher BG (2001) The ecology of Strongylocentrotus droebachiensis. In: Lawrence JM (ed) Edible sea urchins: biology and ecology. Elsevier Science, Amsterdam, p 271-306

Scheibling RE, Hennigar AW, Balch T (1999) Destructive grazing, epiphytism, and disease: the dynamics of sea urchin-kelp interactions in Nova Scotia. Can J Fish Aquat Sci 56:2300-2314

Schmidt AL, Scheibling RE (2005) Population dynamics of an invasive green alga, Codium fragile subsp. tomentosoides, in tidepools on a rocky shore in Nova Scotia, Canada. Ecoscience 12:403-411

Siddon CE, Witman JD (2003) Influence of chronic, low-level hydrodynamic forces on subtidal community structure. Mar Ecol Prog Ser 261:99-110

Sivertsen K (1997) Geographic and environmental factors affecting the distribution of kelp beds and barren grounds and changes in biota associated with kelp reduction at sites along the Norwegian coast. Can J Fish Aquat Sci 54: 2872-2887

Stander PE (1992) Foraging dynamics of lions in a semiarid environment. Can J Zool 70:8-21

Stoner AW, Lally J (1994) High-density aggregation in queen conch Strombus gigas: formation, patterns, and ecological significance. Mar Ecol Prog Ser 106:73-84

Vadas RL, Elner RW, Garwood PE, Babb IG (1986) Experimental evaluation of aggregation behavior in the sea urchin Strongylocentrotus droebachiensis. A reinterpretation. Mar Biol 90:433-448

Velimirov B, Griffiths CL (1979) Wave-induced kelp movement and its importance for community structure. Bot Mar 22:169-172

Winer BJ, Brown DR, Michels KM (1991) Statistical principles in experimental design, 3rd edn. McGraw-Hill, New York

Wright JT, Dworjanyn SA, Rogers CN, Steinberg PD, Williamson JE, Poore AGB (2005) Density-dependent sea urchin grazing: differential removal of species, changes in community composition and alternative community states. Mar Ecol Prog Ser 298:143-156

Submitted: December 8, 2005; Accepted: May 22, 2006

Proofs received from author(s): December 28, 2006 